\title{
A new tall fescue-novel endophyte combination for the south central USA
}

\author{
A.A. HOPKINS and J. H. BOUTON \\ Forage Improvement Division \\ Noble Foundation, Inc. \\ Ardmore, $\mathrm{OK}$ \\ aahopkins@noble.org
}

\begin{abstract}
Tall fescue use has been limited in the south central USA because of insufficient persistence of endophyte free cultivars and poor animal performance from tall fescue infected with wild-type endophyte. Here we report on the development of a tall fescue - novel endophyte combination with improved adaptation to the south central USA. A tall fescue ecotype from Oklahoma was infected with several novel endophytes. Small plot trials were conducted in Oklahoma and Texas to evaluate grazing tolerance, forage yield, and animal safety. One of the ecotypenovel endophyte combinations (AGRFA 144) had greater persistence and forage yield than Jesup MaxQ ${ }^{\circledR}$ in a number of environments. Lamb weight gains from the new tall fescuenovel endophyte combination were comparable to that of Jesup MaxQ and substantially greater than KY-31 infected with a toxic endophyte. Cultivar release of the new tall fescue-novel endophyte combination in 2008 is anticipated.
\end{abstract}

Keywords: novel endophyte, tall fescue, cultivar

\section{Introduction}

Cool season perennial grasses may improve the economics of livestock production versus grazing systems utilising cool season annual grasses. However, poor persistence limits the use of cool season perennial grasses in the southern Great Plains of the USA. Improved stress tolerance, and thus persistence, have been well documented (Popay \& Bonos 2005; Malinowski et al. 2005) for tall fescue infected with an endophyte ([Neotyphodium coenophialum (Morgan-Jones \& Gams.) Glenn, Bacon, \& Hanlin comb. nov.]. Animal toxicity associated with wild-type endophyte is also well documented and reviewed thoroughly (Ball 1997; Stuedemann \& Seman 2005). Non-toxic, novel endophytes offer an opportunity to eliminate animal toxicosis while maintaining high levels of persistence (Bouton et al. 2002; Hopkins \& Alison 2006). Here we report on a new tall fescueendophyte combination that shows promise for improved forage production in the south central USA.

\section{Methods}

A wide array of tall fescue accessions, including Plant Introductions and local ecotypes, were screened for persistence under heavy grazing in south central Oklahoma from 1997 to 1999. Two populations, collected in Oklahoma, were identified as being the most persistent at the conclusion of this trial. Seeds were treated with heat and humidity to remove any viable, wildtype endophyte from these populations, and were then sent to AgResearch in Palmerston North, New Zealand, for inoculation with four different novel endophytes, for a total of eight combinations (coded AGRFA 141 to AGRFA 148). Following initial increase in New Zealand, seed was returned to The Noble Foundation in autumn 2002 and used to establish a Breeder Seed increase at Ardmore, Oklahoma. Grazing tolerance trials were established at Athens, Georgia in a bermudagrass sod, Iowa Park in Texas, and Burneyville in Oklahoma. Plots were grazed heavily during spring and summer, and plant density was determined periodically using a frequency grid method (Hopkins 2005). A forage yield trial was planted in autumn 2003 at Ardmore, Oklahoma and harvested a total of four times from 2004 to 2006. A lamb safety trial was planted at Ardmore in autumn 2003 using AGRFA 142, AGRFA 143, AGRFA 144, AGRFA 148, Jesup $\mathrm{MaxQ}$, and KY-31 E+. Weight gain data were taken from two lambs per paddock, with additional animals added to paddocks using a put and take system to keep forage availability equal between entries. Endophyte infection of tillers was determined using a commercial immunoblot test kit (Agrinostics, Inc.; Watkinsville, GA) following the manufacturers instructions.

\section{Results and Discussion}

\section{Endophyte transmission}

High levels of fungus transmission are essential to success of a tall fescue cultivar containing a novel endophyte. The combinations AGRFA 141, AGRFA 142, and AGRFA 145 produced progeny with infection rates approximately $65 \%$ or less, and were therefore dropped from consideration for cultivar development. All other combinations produced seed with infection rates of $80 \%$ or greater, with the AGRFA 144 combination approaching $100 \%$ in some instances.

\section{Grazing tolerance}

Persistence, as indicated by tall fescue stand density, of the eight combinations was statistically not different from Jesup MaxQ two and half years after planting at Georgia, Texas, or Oklahoma. However, the combinations AGRFA 144 and AGRFA 148 had consistently numerically greater tall fescue stands than Jesup MaxQ at these locations. Subsequent trials at other locations in Oklahoma and Texas produced similar results. It should be noted that tall fescue stands for all combinations in these trials after two and half years averaged 0 to $40 \%$, indicating poor adaptation of continental-type tall fescue to the south central and Coastal Plains regions of the USA.

\section{Forage yield}

Total forage yield ( $\mathrm{kg} \mathrm{DM} / \mathrm{ha}$ ) from 2004 to 2006 was significantly greater $(\mathrm{P}<0.05$ for AGRFA 144 (10 833) than AGRFA 148 (8 665) and Jesup MaxQ (9 041). Most of this yield advantage can probably be attributed to greater productivity of AGRFA 144 in autumn 2004. Precipitation averaged less than $60 \%$ of normal, with warmer than normal temperatures from October 2005 to September 2006 at Ardmore, with the end result being that all entries in this clipping trial, except a summer dormant experimental line, failed to persist.

\section{Animal safety}

Weight gain of lambs grazing non-toxic, novel endophyte tall fescue entries averaged $60 \%, 340 \%$, and $111 \%$ greater than lambs grazing KY-31 E+ in spring 2004, autumn 2005, and spring 2006, respectively. This dramatically illustrates the greater animal performance and health that is possible by using tall fescue 
containing a novel rather than wild-type endophyte. Weight gains (g/day) in spring 2006 were not significantly different for AGRFA 144 (153), AGRFA 148 (136), and Jesup MaxQ (120). As with the forage yield trial at Ardmore, severe drought caused substantial tall fescue plant loss by autumn 2006, with tall fescue stand density ranging from 8 to $22 \%$. No significant differences for persistence between entries occurred.

Beef cattle performance trials are currently underway at Ardmore comparing AGRFA 144 to a cool season annual grass system; beef cattle performance trials comparing AGRFA 144 to Jesup MaxQ have also been established in Oklahoma and Arkansas. Data are also being gathered at numerous locations in the USA from additional small plot forage yield, seed yield and grazing tolerance trials to compare AGRFA 144 with Jesup MaxQ and other novel endophyte-tall fescue combinations.

Based on data gathered to date, AGRFA 144 is comparable to Jesup MaxQ in terms of persistence and animal performance, and appears to have a forage yield advantage of as much as $10 \%$. Seed yields of AGRFA 144 in the Pacific Northwest USA have also been encouraging. As a result, we anticipate release of AGRFA 144 as a named cultivar circa 2008.

\section{REFERENCES}

Ball, D.M. 1997. Significance of endophyte toxicoses and current practices in dealing with the problem in the United States. pp.
395-410. In: Neotyphodium/Grass Interactions. Eds. Bacon, C.W.; Hill, N.S. Plenum Press, New York.

Bouton, J.H.; Latch, G.C.M.; Hill, N.S.; Hoveland, C.S.; McCann, M.A.; Watson, R.H.;

Parish, J.A.; Hawkins, L.L.; Thompson. F.N. 2002. Reinfection of tall fescue cultivars with non-ergot alkaloid-producing endophytes. Agronomy Journal 94: 567-574.

Hopkins, A.A. 2005. Grazing tolerance of cool-season grasses planted as seeded sward plots and spaced plants. Crop Science 45: 1559-1564.

Hopkins, A.A.; Alison, M.W. 2006. Stand persistence and animal performance for tall fescue endophyte combinations in the south central USA. Agronomy Journal 98: 1221-1226.

Malinowski, D.P.; Belesky, D.P.; Lewis, G.C. 2005. Abiotic stresses in endophytic grasses. pp. 187-199. In: Neotyphodium in Cool-Season Grasses. Eds. Roberts, C.A.; West, C.P.; Spiers, D.E. Blackwell Publishing, Ames, IA.

Popay, A.J.; Bonos, S.A. 2005. Biotic responses in endophytic grasses. pp. 163-185. In: Neotyphodium in Cool-Season Grasses. Eds. Roberts, C.A.; West, C.P.; Spiers, D.E. Blackwell Publishing, Ames, IA.

Stuedemann, J.A.; Seman, D.H. 2005. Integrating genetics, environment, and management to minimize animal toxicoses. pp. 305-324. In: Neotyphodium in Cool-season Grasses. Roberts, C.A.; West, C.P.; Spiers, D.E. Blackwell Publishing, Ames, IA. 